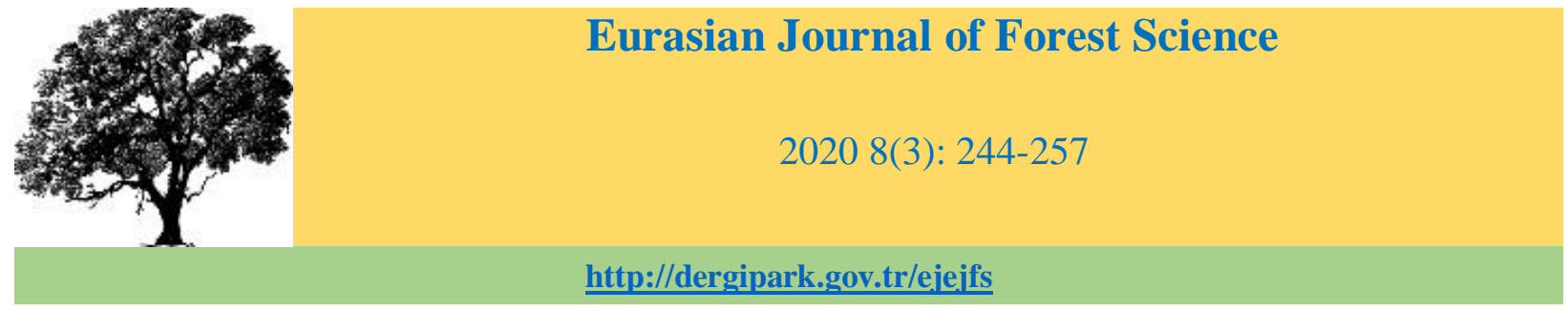

\title{
Some fossil conifer species descriptions from the Paleogene to Pliocene of Turkey and their evaluations
}

\author{
Ünal Akkemik \\ Istanbul University-Cerrahpasa, Forestry Faculty, Forest Botany Department, 34473 Bahceköy, Istanbul, Turkey \\ Corresponding author: uakkemik@istanbul.edu.tr
}

\begin{abstract}
Until now, a considerable number of Miocene conifer trees has been determined using fossil wood identification. Some studies on fossil wood identifications have revealed the need to reconsider certain fossil wood species definitions. The present study aimed to re-analysis the conifer wood identifications (Cupressaceae), which were described as genus, and performed necessary revisions in the descriptions. All studies were conducted on thin sections used in former studies, and detailed investigations were performed. As result, Cupressinoxylon pliocenica Akkemik, 2019, Glyptostroboxylon rudolphii Dolezych \& van der Burgh, 2004, and Taxodioxylon gypsaceum (Göppert) Kräusel, 1949, were described in Turkey. This study showed that these three fossil species had wider distribution areas and lived in a very wide time interval from mainly early Miocene to Pliocene in Turkey.
\end{abstract}

Keywords: Cupressinoxylon pliocenica, Glyptostroboxylon rudolphii, Taxodioxylon gypsaceum, Turkey, fossil species

\section{Introduction}

Petrified wood identifications in Turkey started in 1970s and increased in the first quarter of $21^{\text {st }}$ century. A considerable number of petrified woods have been identified from the late Oligocene, Miocene, and Pliocene in Turkey.

The increased number of the palaeobotanical studies in Turkey showed the presence of a diverse conifer genera such as Araucarioxylon, Pinuxylon, Lesbosoxylon, Cupressinoxylon, Taxodioxylon, Glyptostroboxylon, Sequoioxylon Juniperus, Taxoxylon (Kayac1k et al., 1995; Selmeier, 2001; Akkemik et al., 2005; Kutluk et al., 2012; Akkemik and Sakınç, 2013; Akkemik et al., 2009, 2016, 2017, 2019a,b, 2020; Acarca Bayam et al., 2018; Akkemik, 2019; Akkemik and Acarca Bayam, 2019; Güngör et al., 2019).

In some of the studies, the fossil species of these genera were identified such as Sequoioxylon egemenii Özgüven-Ertan, 1971 (Özgüven-Ertan, 1971), Cupressinoxylon akdiki Özgüven-Ertan, 1977 (ÖzgüvenErtan, 1977), Sequoioxylon gypsaceum (Göppert) Greguss, 1967 (Özgüven-Ertan, 1981 (1983), Taxodioxylon gypsaceum (Göppert) Kräusel, 1949, Glyptostroboxylon rudolphii Dolezych \& van der Burgh 2004 (Akkemik and Bayam, 2019), and Cupressinoxylon pliocenica Akkemik 2019 (Akkemik, 2019).

The most of the members of Cupressaceae were identified as genus level (e.g. Akkemik et al., 2009; Akkemik and Sakınç, 2013; Akkemik et al., 2017; Acarca Bayam et al., 2018; Akkemik et al., 2019a; 
Güngör et al., 2019). In the fossil specimens, which were fossilized in good conditions, a revision may be done, and possible fossil species of these genera may be described. It may also be discussed their species diversity and distributions in geological times and geographic areas. Therefore, the purpose of the present study is to restudy the identifications of the fossil Cupressinoxylon, Glyptostroboxylon, Sequoioxylon and Taxodioxylon genera of Cupressaceae, and to describe their fossil species, whenever it is possible.

\section{Material and Methods}

While certain conifer woods were identified at the species level, some others were identified at the genus level (Table 1).

The present study focused on the some Cupressaceae woods identified at the genus level, and used thin sections of the fossil (petrified) woods utilized in the previous studies as materials, obtained from different locations from the west-central Anatolia to the European part of Turkey (Figure 1).

Studies were performed on the thin wood sections of Cupressinoxylon, Glyptostroboxylon, Sequoioxylon and Taxodioxylon (Kayacık et al., 1995; Akkemik et al., 2005; Akkemik et al., 2009; Akkemik et al., 2016; Acarca Bayam et al., 2018; Akkemik et al., 2019a; Güngör et al., 2019; Polat et al., 2019) (Table 1). For identification at the species level, the published descriptions given in the relevant discussion parts of the related species were used.

Table 1. The restudied fossil conifer woods identified from the Cenozoic era of Turkey

\begin{tabular}{|c|c|c|c|c|c|}
\hline Age & Identification & Code & Locality & Formation & Reference \\
\hline Paleogene & $\begin{array}{l}\text { Sequoioxylon } \\
\text { Torrey } 1923\end{array}$ & USA01 & $\begin{array}{l}\text { Küçuikler area in the } \\
\text { west of the city of Banaz } \\
\text { of the province of Uşak }\end{array}$ & - & Polat et al. (2019) \\
\hline Early Miocene & $\begin{array}{l}\text { Cupressinoxylon } \\
\text { Göppert } 1850\end{array}$ & GOK04 & $\begin{array}{l}\text { East of Eşelek Village - } \\
\text { Gökçeada, and near to the } \\
\text { coastline. }\end{array}$ & $\begin{array}{l}\text { Kesmekaya } \\
\text { Volcanics }\end{array}$ & Güngör et al. (2019) \\
\hline Early Miocene & $\begin{array}{l}\text { Sequoioxylon } \\
\text { Torrey } 1923\end{array}$ & GOK211 & $\begin{array}{l}\text { East of Eşelek Village - } \\
\text { Gökçeada, and near to the } \\
\text { coastline. }\end{array}$ & $\begin{array}{l}\text { Kesmekaya } \\
\text { Volcanics }\end{array}$ & Güngör et al. (2019) \\
\hline Early Miocene & $\begin{array}{l}\text { Sequoioxylon } \\
\text { Torrey } 1923\end{array}$ & DUR02 & $\begin{array}{l}\text { Alaçam Village of the city } \\
\text { of Dursunbey }\end{array}$ & Beke Formation & $\begin{array}{l}\text { Akkemik et al. } \\
(2019 a)\end{array}$ \\
\hline Early Miocene & $\begin{array}{l}\text { Sequoia (D. Don.) } \\
\text { Endlicher } 1847\end{array}$ & INO04 & Beypazarı Inozu Valley & $\begin{array}{l}\text { Hançili } \\
\text { Formation }\end{array}$ & $\begin{array}{l}\text { Acarca Bayam et al. } \\
\text { (2018) }\end{array}$ \\
\hline Early Miocene & $\begin{array}{l}\text { Sequoioxylon } \\
\text { Torrey } 1923\end{array}$ & & $\begin{array}{l}\text { European Part of Turkey } \\
\text { (Thrace) }\end{array}$ & $\begin{array}{l}\text { Hisarlı Dağ } \\
\text { Volcanics }\end{array}$ & $\begin{array}{l}\text { Akkemik \& Sakınç } \\
\text { (2013) }\end{array}$ \\
\hline $\begin{array}{l}\text { Early-Middle } \\
\text { Miocene }\end{array}$ & $\begin{array}{l}\text { Sequoia (D. Don.) } \\
\text { Endlicher } 1847\end{array}$ & BUG20 & $\begin{array}{l}\text { the villages of Çamlidere- } \\
\text { Buğralar }\end{array}$ & Pazar Formation & $\begin{array}{l}\text { Acarca Bayam et al. } \\
(2018)\end{array}$ \\
\hline $\begin{array}{l}\text { Early-Middle } \\
\text { Miocene }\end{array}$ & $\begin{array}{l}\text { Sequoia (D. Don.) } \\
\text { Endlicher } 1847\end{array}$ & SOG04 & Kızılcahamam-Soğuksu & Pazar Formation & $\begin{array}{l}\text { Acarca Bayam et al. } \\
(2018)\end{array}$ \\
\hline $\begin{array}{l}\text { Early-Middle } \\
\text { Miocene }\end{array}$ & $\begin{array}{l}\text { Taxodium Richard } \\
1810\end{array}$ & BUG01 & $\begin{array}{l}\text { the villages of Çamlidere- } \\
\text { Buğralar }\end{array}$ & Pazar Formation & $\begin{array}{l}\text { Acarca Bayam et al. } \\
(2018)\end{array}$ \\
\hline $\begin{array}{l}\text { Early-Middle } \\
\text { Miocene }\end{array}$ & $\begin{array}{l}\text { Taxodium Richard } \\
1810\end{array}$ & CAM01 & Ankara-Çamlıdere & Pazar Formation & Akkemik et al. (2009) \\
\hline $\begin{array}{l}\text { Early-Middle } \\
\text { Miocene }\end{array}$ & $\begin{array}{l}\text { Sequoia (D. Don.) } \\
\text { Endlicher } 1847\end{array}$ & CAM2 & Ankara-Çamlıdere & Pazar Formation & Akkemik et al. (2009) \\
\hline $\begin{array}{l}\text { Early-Middle } \\
\text { Miocene }\end{array}$ & $\begin{array}{l}\text { Glyptostroboxylon } \\
\text { Conwentz }\end{array}$ & $\begin{array}{l}\text { GUD02, } \\
\text { GUD05 }\end{array}$ & Ankara-Güdül & Pazar Formation & Akkemik et al. (2017) \\
\hline Pliocene & $\begin{array}{l}\text { Sequoioxylon } \\
\text { Torrey } 1923\end{array}$ & CUK07 & $\begin{array}{l}\text { Çukurköy near Tunçbilek } \\
\text { in the city of Tavşsnl, } \\
\text { Kütahya }\end{array}$ & $\begin{array}{l}\text { Çokköy } \\
\text { Formation }\end{array}$ & $\begin{array}{l}\text { Akkemik et al. } \\
(2019 a)\end{array}$ \\
\hline
\end{tabular}




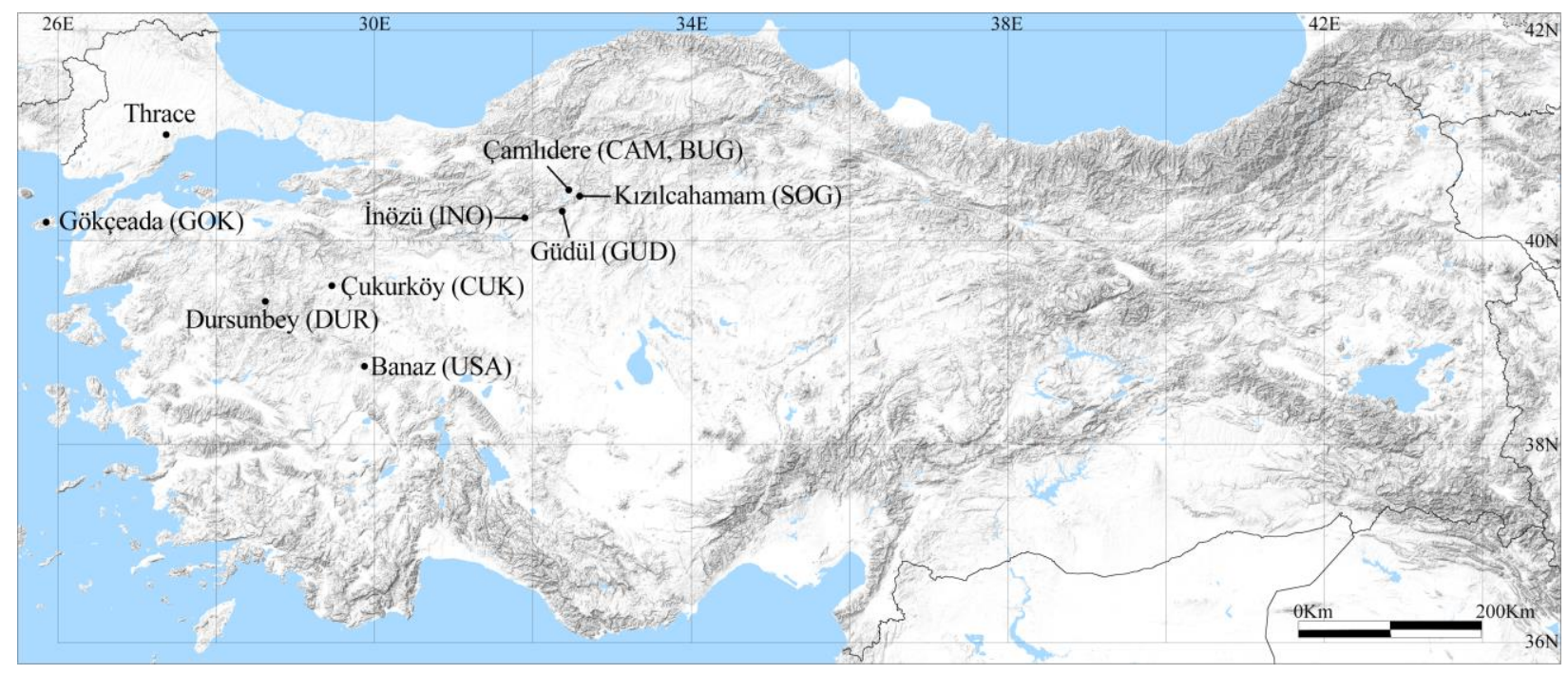

Figure 1. The location map of the revisited specimens in Turkey.

\section{Systematic palaeobotany}

In this study, the fossil species, Cupressinoxylon pliocenica Akkemik, 2019, Glyptostroboxylon rudolphii Dolezych \& van der Burgh 2004, and Taxodioxylon gypsaceum (Göppert) Kräusel 1949, were identified.

Order PINALES Gorozhankin, 1904

Family CUPRESSACEAE Gray, 1822

Genus CUPRESSINOXYLON (Goeppert) emend. Dolezych 2005

Cupressinoxylon pliocenica Akkemik, 2019

Formation: Kesmekaya Volcanics. The detailed geology of the area was given by Güngör et al. (2019).

Age: Early Miocene

Locality: East of Eşelek Village - Gökçeada, and near to the coastline.

Sample code: GOK04

Diagnosis: The wood anatomical characteristics of Cupressinoxylon given by Güngör et al. (2019) were restudied here and the diagnosis were designed as follows: Growth ring border distinct with 1-5 rows of radially flattened latewood tracheids, transition from earlywood to the latewood gradual. Tracheids polygonal, irregularly shaped or slightly circular. Normal axial and horizontal resin canals absent. Axial parenchyma common, diffuses, short diffuse-in-aggregate and marginal; dark content very common in axial parenchyma cells (Figure 2: A-B). Rays predominantly uniseriate and very rarely and partly biseriate, ray heights 3-13 (1-23) cells (Figure 2:C). Rays homogenous, end walls of ray cells commonly smooth, 2-3 (14) cupressoid type of cross-field pits present (Figure 2: D and G). Tracheidal pits on radial walls predominantly uniseriate, rarely partly biseriate (Figure 2: E). Tracheidal pits also common on tangential walls of tracheids. End walls of axial parenchyma smooth in general (Figure 2: F).

Discussion: Cupressinoxylon is one of the most common genera identified from Cretaceous to Pliocene, and, until now, more than 130 fossil species were described (Vaudois and Prive, 1971; Özgüven-Ertan, 1977; Duperon-Laudoueneix, M., 1979; Nishida, 1984, 1988; Bamford et al., 2002; Herbst et al., 2007; Philippe and Bamford, 2008; Martínez, 2010; Klusek 2014; Bodnar et al. 2015; Pujana et al., 2014, 2015; Akkemik, 2019). 

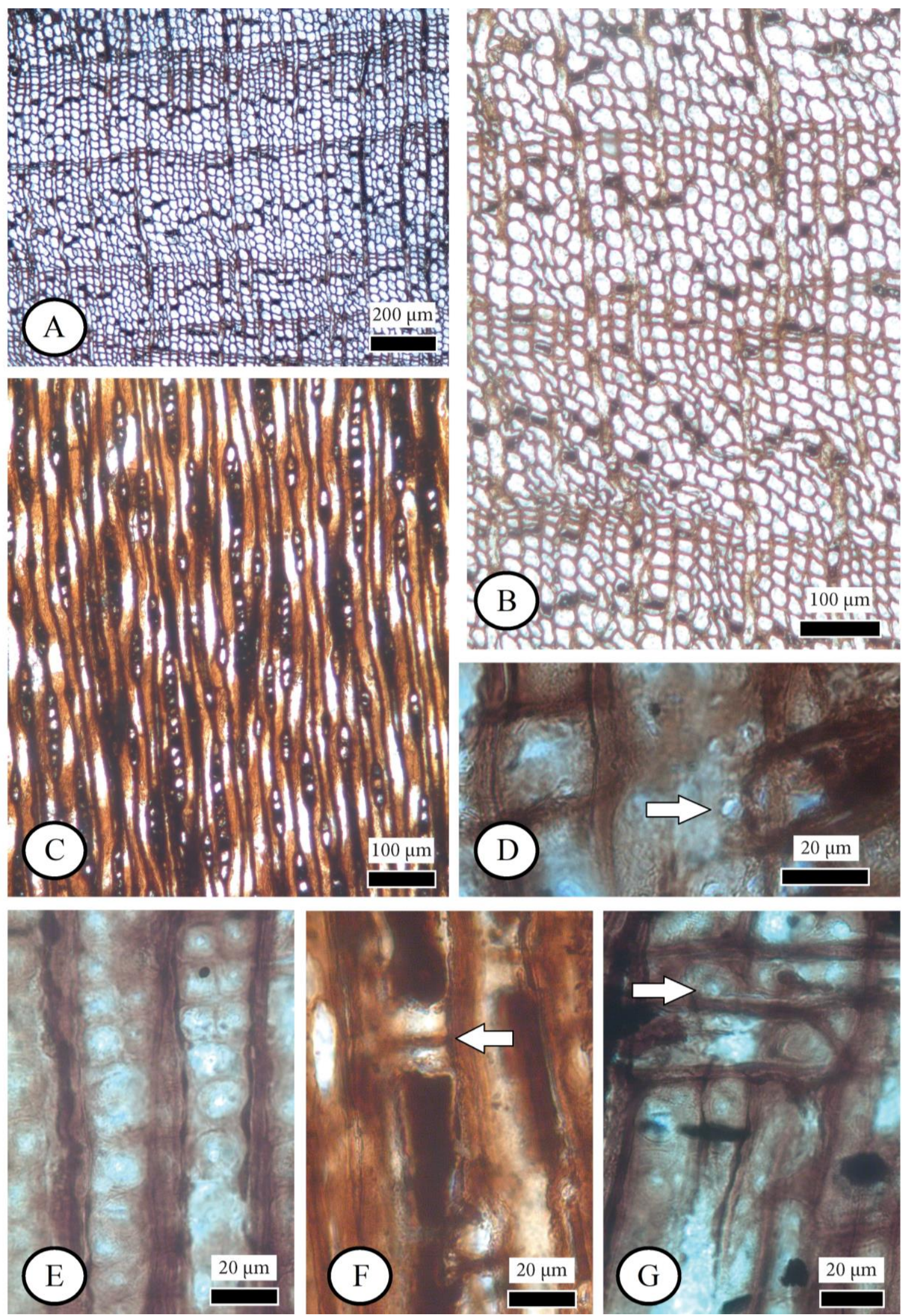

Figure 2. The thin sections of Cupressinoxylon pliocenica. A-B) Transversal sections with dense axial parenchyma and without resin canal, C) Tangential section, D) Cupressoid type cross-field pits (arrow), E) Generally uniseriate tracheidal pits on radial surface and rarely biseriate pits, F) Almost smooth horizontal-walled axial parenchyma (arrow), G) A radial section and cupressoid type cross-field pits (arrow). 
After the species of Cupressinoxylon were revised by Dolezych-Mikolai (2005) and Klusek (2014), the latest species of the fossil genus was described by Akkemik (2019) as Cupressinoxylon pliocenica from the Pliocene of the north-central Anatolia (Çankırı-Çerkeş-Yıprak Village). The studied Cupressinoxylon specimen was compared first with this fossil species (Table 2).

Table 2. Comparison Cupressinoxylon pliocenica Akkemik (Akkemik, 2019) and the re-studied Cupressinoxylon.

\begin{tabular}{lll}
\hline Features & $\begin{array}{l}\text { Cupressinoxylon pliocenica } \\
\text { (Akkemik, 2019) }\end{array}$ & The studied Cupressinoxylon specimen \\
\hline Growth ring & $\begin{array}{l}\text { Growth ring boundaries distinct. Transition } \\
\text { from earlywood to latewood gradual. }\end{array}$ & $\begin{array}{l}\text { Growth ring border distinct, transition } \\
\text { from earlywood to latewood indistinct. }\end{array}$ \\
\hline Tracheids & $\begin{array}{l}\text { Tracheid pitting in radial walls in earlywood } \\
\text { predominantly uniseriate. Intercellular spaces } \\
\text { throughout the wood in transversal section } \\
\text { observed. Latewood tracheids thick-walled. }\end{array}$ & $\begin{array}{l}\text { Tracheid pitting in radial walls uniseriate } \\
\text { and rounded; Intercellular spaces present. } \\
\text { Latewood tracheids thick-walled. }\end{array}$ \\
\hline Rays & $\begin{array}{l}\text { Number of pits per cross-field 2 to 4 (mostly } \\
\text { 2), and their angle about 45 } \text { or more. Average } \\
\text { ray height 5-15 cells. Max ray height 34 cells. }\end{array}$ & $\begin{array}{l}\text { Number of pits per cross-field 2-3 (1-4), } \\
\text { Average ray height 3-10 (1-23) cells. }\end{array}$ \\
\hline $\begin{array}{l}\text { Axial } \\
\text { parenchyma }\end{array}$ & $\begin{array}{l}\text { Axial parenchyma common. End walls of } \\
\text { axial parenchyma cells smooth and nodular. }\end{array}$ & $\begin{array}{l}\text { Axial parenchyma present and abundant. } \\
\text { End walls of axial parenchyma cells } \\
\text { smooth and nodular. }\end{array}$ \\
\hline
\end{tabular}

Based on the strong similarities between the studied Cupressinoxylon specimen and Cupressinoxylon pliocenica, it was described as Cupressinoxylon pliocenica (Table 2). At present, the genus Cupressus is represented with a common species called Mediterranean cypress (C. sempervirens L.), and it distributes throughout the Mediterranean basin. Akkemik (2019) suggested that $C$. pliocenica has close wood characteristics to this modern species, $C$. sempervirens. The results at the present study showed also that the new Cupressinoxylon wood was also close to the modern species. It may be suggested that Cupressinoxylon has a long history from early Miocene to the present in Anatolia, and showed mostly stable wood anatomical features through the Neogene.

\section{Genus GLYPTOSTROBOXYLON Conwentz, 1884 emend. Dolezych \& Van der Burgh 2004 Glyptostroboxylon rudolphii Dolezych \& van der Burgh 2004}

Formation: Pazar Formation. The detailed geology of the area was given by Akkemik et al. (2017).

Age: Early-Middle Miocene.

Locality: Near the city of Güdül.

Sample code: GUD06.

Diagnosis: Wood anatomical characteristics were given based on new observations and Akkemik et al. (2017) as follows. Diagnosis of the wood showed the following features: Growth rings generally distinct with 1-3 rows of flattened latewood tracheids. Transition from earlywood to latewood gradual and indistinct. Earlywood zone is distinctly wider than latewood zone. Normal axial and horizontal resin canals absent. Tracheids generally polygonal and hexagonal in outline in transverse section. Axial parenchyma presents, tangentially zonate and diffuse (Figure 3: A). Rays predominantly uniseriate, rarely biseriate, height of rays 2-5 (1-11) cells (Figure 3: B). End walls of axial parenchyma thin and slightly dentate or smooth (Figure 3: C). Helical thickenings absent. Horizontal and tangential end walls of ray cells smooth (unpitted), and ray tracheids absent. Cross-field pits predominantly glyptostroboid and rarely taxodioid, and number of pits 2-6 per cross-field (Figure 3: D). Tracheidal pitting on radial walls circular in outline, and 1-3 seriate, and crassulae present (Figure 3: E-F). 

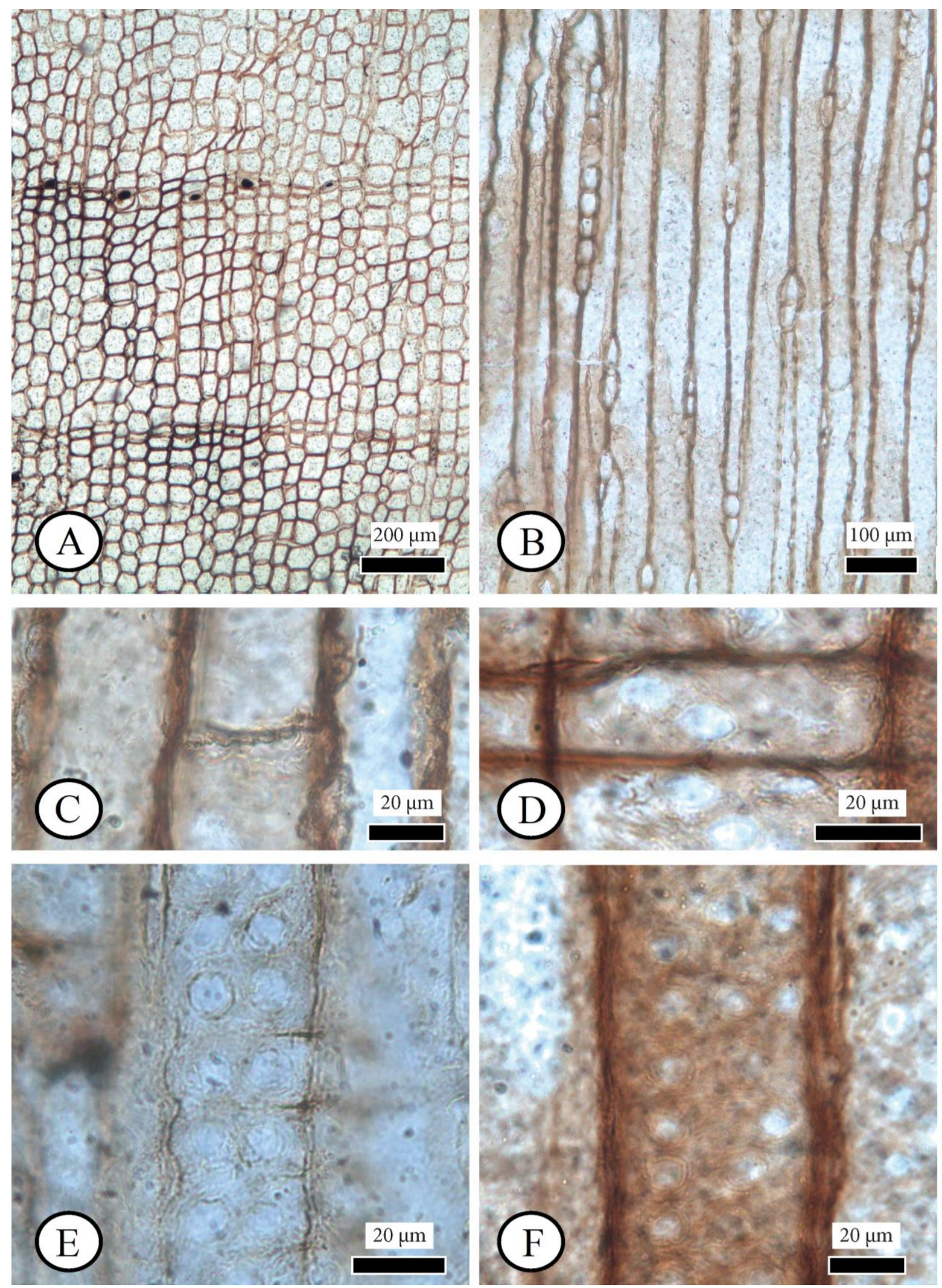

Figure 3. The thin sections of Glyptostroboxylon rudolphii. A) Transversal section with 1-2 rows of flattened latewood tracheids, and without resin canals, B) Tangential section, C) Axial parenchyma with smooth end walls, D) Glyptostroboid type cross-field pits, E-F) 2-3 rows of tracheidal pits of radial surface. 
Discussion: Three species of Glyptostroboxylon were described (Süss and Velitzelos, 1997; Teodoridis and Sakala, 2008; Dolezych, 2011; Akkemik et al., 2017; Akkemik and Acarca Bayam, 2019). The following identification key was prepared for these three fossil species:

1A. Radial tracheidal wall pits uniseriate and no crassulae formation; 1-2 glyptostroboid type of pits per cross-field > Glyptostroboxylon tenerum (Kraus) Conwentz 1884

1B. Radial tracheidal wall pits uni- to triseriate and, if biseriate, crassulae presents

2A. Tracheids are very small; intercellular spaces between tracheids and rays present; horizontal walls of rays in the crossing area strongly thickened with tangential walls > Glyptostroboxylon microtracheidale Süss \& Velitzelos 1997

2B. Tracheids not small; tracheidal pitting on radial walls up to triseriate; 1-4 glyptostroboid type of pits per cross-field > Glyptostroboxylon rudolphii Dolezych \&van der Burgh 2004

According to the identification key, the fossil Glyptostroboxylon from Güdül should be G. rudolphii due to having tracheidal pits up to triseriate, crassulae formation, and wider tracheids. Moreover, the fossil wood sample SOG04, identified as Sequoia (Acarca Bayam et al., 2018) from the same geologic formation (Pazar formation), has also glyptostroboid cross-field pits together with taxodioid pits and smooth end wall of axial parenchyma and indistinct transition from earlywood to latewood, and one to five rows of latewood tracheids. According to the identification key, this fossil wood may be Glyptostroboxylon rudolphii.

Further, this fossil species was identified from the late Miocene fossil woods found in the east Galatian Volcanic Province (Akkemik and Acarca Bayam, 2019) and from the mid-late Miocene of Kütahya in central Turkey (Akkemik et al., 2019a). Finally, this fossil species had a wide distribution area during the early-middle Miocene to the late Miocene in the swamp areas of central Turkey. Today, this genus and its swamp conditions are completely extinct from Turkey.

Genus TAXODIOXYLON Hartig 1848 emend. Gothan 1905

Taxodioxylon gypsaceum (Göppert) Kräusel 1949

(Syn: Sequoioxylon gypsaceum (Göppert) Greguss 1967)

The samples identified as Sequoioxylon given below (Table 3) were re-analyzed and compared with the most related species, Taxodioxylon (=Sequoioxylon) gypsaceum.

Diagnosis: The wood features were summarized based on the results of the related studies (Table 3) and new observations: Growth ring boundary distinct with 2-10 radially flattened latewood tracheids, transition from earlywood to latewood mostly abrupt and clear latewood zone presents. Tracheid cells generally polygonal and sometimes rounded. Axial parenchyma diffuses and zonate. Resin and intercellular canals absent. (Figure 4: A). Rays uniseriate, rarely partly biseriate, ray height 1-32 cells (Figure 4: B). End walls of axial parenchyma smooth and slightly nodular (Figure 4: C). Rays homogenous, cross-field pits taxodioid, 2-4 pits per cross-fields (Figure 4: D). Ray tracheids absent or partly present, end and horizontal walls of rays smooth. Tracheidal ray pits 1-3 seriate, opposite, and crassulae presents (Figure 4: E).

Discussion: The comparison of the wood characteristics of Taxodioxylon gypsaceum (Greguss, 1967; Özgüven-Ertan 1981 (1983); Dolezych, 2011; Iamandei et al., 2013; Koutecký and Sakala, 2015; Akkemik et al., 2019a; Akkemik, 2019) with the specimens identified as Sequoioxylon and Taxodioxylon showed that all these woods are close to each other, and they should be belonging to Taxodioxylon gypsaceum. 
Table 3. Sequoioxylon identification and their comparison with Taxodioxylon gypsaceum. All these woods showed most stable wood characteristics from Paleocene to Pliocene.

\begin{tabular}{|c|c|c|c|c|c|c|c|c|}
\hline Features & $\begin{array}{l}\text { Sequoioxylon } \\
\text { Polat et al. } \\
\text { (2019) }\end{array}$ & $\begin{array}{c}\text { Sequoioxylon } \\
\text { Akkemik and Sakınç } \\
\text { (2013) }\end{array}$ & $\begin{array}{l}\text { Sequoioxylon Kayacık } \\
\text { et al., (1995); Akkemik } \\
\text { et al. (2005) }\end{array}$ & $\begin{array}{l}\text { Sequoioxylon } \\
\text { Akkemik et al. } \\
\quad(2019 b) .\end{array}$ & $\begin{array}{l}\text { Sequoioxylon } \\
\text { Güngör et al. } \\
\quad \text { (2019) }\end{array}$ & $\begin{array}{c}\text { Sequoia } \\
\text { Akkemik et al. } \\
(2009)\end{array}$ & $\begin{array}{l}\text { Sequoioxylon } \\
\text { Akkemik et al. } \\
\text { (2019b) }\end{array}$ & $\begin{array}{c}\text { Taxodioxylon (Sequoioxylon) } \\
\text { gypsaceum } \\
\text { Greguss (1967); Özgüven-Ertan } \\
\text { (1981 (1983)); Dolezych (2011); } \\
\text { Iamandei et al. (2013); Koutecký } \\
\text { and Sakala (2015); Biondi and } \\
\text { Brungiapaglia (1991) }\end{array}$ \\
\hline Locality /Code & $\begin{array}{l}\text { Uşak-Banaz } \\
\text { (USA) }\end{array}$ & Thrace & $\begin{array}{l}\text { North of Istanbul } \\
\text { (Thrace) }\end{array}$ & $\begin{array}{l}\text { Dursunbey } \\
\text { (DUR02) }\end{array}$ & $\begin{array}{l}\text { Gökçeada } \\
\text { (GOK211) }\end{array}$ & $\begin{array}{l}\text { Camlidere } \\
\text { (CAM2-01) }\end{array}$ & $\begin{array}{l}\text { Çukurköy } \\
\text { (CUK07) }\end{array}$ & 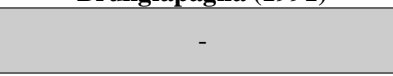 \\
\hline Age & Paleocene & Mid-Late Oligocene & Late Oligocene & Early Miocene & Early Miocene & $\begin{array}{l}\text { Early-Middle } \\
\text { Miocene }\end{array}$ & Pliocene & - \\
\hline Formation & - & $\begin{array}{l}\text { Danişmen-Osmancik } \\
\text { Formation }\end{array}$ & $\begin{array}{l}\text { Danişment-Çöpköy } \\
\text { Formation }\end{array}$ & Beke Formation & $\begin{array}{l}\text { Kesmekaya } \\
\text { Volcanics }\end{array}$ & $\begin{array}{c}\text { Pazar } \\
\text { Formation }\end{array}$ & $\begin{array}{c}\text { Çokköy } \\
\text { Formation }\end{array}$ & \\
\hline $\begin{array}{l}\text { Growth ring } \\
\text { boundary }\end{array}$ & Distinct & Distinct & Distinct & Distinct & Distinct & Distinct & Distinct & Distinct \\
\hline $\begin{array}{l}\text { Earlywood to } \\
\text { latewood transition }\end{array}$ & $\begin{array}{l}\text { abrupt with } \\
\text { wide zone ( } 2-15 \\
\text { rows) of LW }\end{array}$ & $\begin{array}{l}\text { abrupt with wide zone } \\
\text { (2-10 rows) of LW }\end{array}$ & $\begin{array}{l}\text { abrupt with wide zone } \\
\text { (2-10 rows) of } L W\end{array}$ & $\begin{array}{l}\text { abrupt with wide } \\
\text { zone ( } 2-11 \text { rows) } \\
\text { of } L W\end{array}$ & $\begin{array}{c}\text { Gradual and } \\
\text { abrupt with wide } \\
\text { zone ( } 2-13 \text { rows) } \\
\text { of } L W\end{array}$ & $\begin{array}{l}\text { abrupt with } \\
\text { wide zone (>10 } \\
\text { rows) of LW }\end{array}$ & $\begin{array}{c}\text { abrupt with } \\
\text { wide zone ( } 2-22 \\
\text { rows) of LW }\end{array}$ & Abrupt with wide zone of LW \\
\hline Resin canal & Absent & Absent & Absent & Absent & Absent & Absent & Absent & Absent \\
\hline Axial parenchyma & $\begin{array}{l}\text { Diffuse to } \\
\text { tangentially } \\
\text { zonate }\end{array}$ & $\begin{array}{l}\text { Diffuse to tangentially } \\
\text { zonate }\end{array}$ & $\begin{array}{l}\text { Diffuse to tangentially } \\
\text { zonate }\end{array}$ & $\begin{array}{l}\text { Diffuse to } \\
\text { tangentially } \\
\text { zonate }\end{array}$ & $\begin{array}{l}\text { Diffuse to } \\
\text { tangentially } \\
\text { zonate }\end{array}$ & $\begin{array}{l}\text { Diffuse to } \\
\text { tangentially } \\
\text { zonate }\end{array}$ & $\begin{array}{l}\text { Diffuse to } \\
\text { tangentially } \\
\text { zonate }\end{array}$ & Diffuse to tangentially zonate \\
\hline $\begin{array}{l}\text { End walls of axial } \\
\text { parenchyma }\end{array}$ & $\begin{array}{l}\text { Seemingly } \\
\text { smooth }\end{array}$ & $\begin{array}{l}\text { Smooth, slightly } \\
\text { nodular }\end{array}$ & Smooth, slightly nodular & Seemingly smooth & $\begin{array}{c}\text { Smooth, slightly } \\
\text { nodular }\end{array}$ & $\begin{array}{l}\text { Seemingly } \\
\text { smooth }\end{array}$ & $\begin{array}{l}\text { Seemingly } \\
\text { smooth }\end{array}$ & Smooth, slightly nodular \\
\hline Intercellular canals & & Absent & Absent & Absent & Absent & Absent & Absent & Absent \\
\hline Ray width & Uniseriate & Uniseriate & Uniseriate & Uniseriate & $\begin{array}{l}\text { Uniseriate, rarely } \\
\text { partly biseriate }\end{array}$ & Uniseriate & Uniseriate & Uniseriate, rarely partly biseriate \\
\hline Ray height & $5-40$ & $5-33$ & $2-61$ & $2-31$ & $3-35$ & $5-33$ & $2-31$ & $1-33$ \\
\hline Helical thickening & Absent & Absent & Absent & Absent & Absent & Absent & Absent & Absent \\
\hline $\begin{array}{l}\text { Tracheidal pit } \\
\text { arrangement }\end{array}$ & $\begin{array}{l}\text { Uni-biseriate, } \\
\text { opposite }\end{array}$ & 1-3 (-4), opposite & Uni-biseriate, opposite & 1-2 (-3), opposite & 1-2 (-3), opposite & $\begin{array}{l}1-3(-4), \\
\text { opposite }\end{array}$ & $\begin{array}{l}1-2(-3), \\
\text { opposite }\end{array}$ & $1-3$ \\
\hline Cross-field pitting & $?$ & $2-6$ & $2-8$ & $2-5$ & $2-5$ & $1-6$ & $2-5$ & $1-5$ \\
\hline Ray cell end walls & Smooth & Smooth & Smooth & Smooth & Smooth & Smooth & Smooth & Smooth \\
\hline $\begin{array}{l}\text { Ray cell horizontal } \\
\text { walls }\end{array}$ & Smooth & Smooth & Smooth & Smooth & Smooth & Smooth & Smooth & Smooth \\
\hline Ray tracheids & Absent & Absent & Partly present & Absent & Absent & Absent & Absent & Absent \\
\hline
\end{tabular}



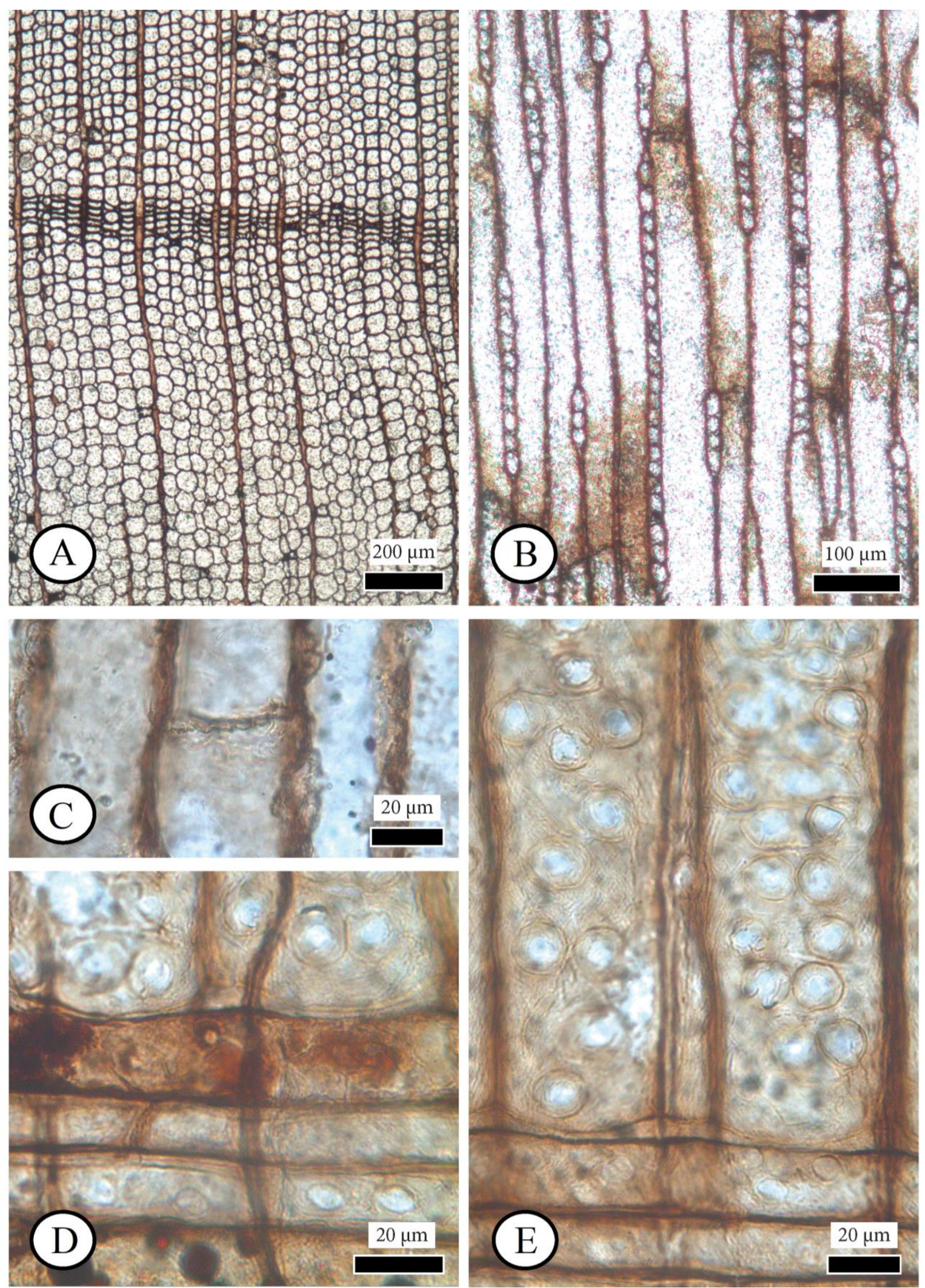

Figure 4. The thin sections of Taxodioxylon gypsaceum. A) Transversal section with axial parenchyma and without axial resin canals, B) Long uniseriate rays in tangential section, C) A slightly nodular end wall of axial parenchyma, D) Taxodioid type of cross-field pits, E) 2-3 seriate of pits on radial walls of tracheids. 
Based on the recent discussion on the names of Taxodioxylon and Sequoioxylon (Blokhina et al., 2010; Tian et al., 2018), I prefer to use the name Taxodioxylon, as I used in my recent studies (Akkemik, 2019 and Akkemik et al., 2019a). The results showed that T. gypsaceum was identified from different time periods from Paleogene to Pliocene. It may be suggested that it was one of the most common fossil tree species in Cenozoic era of Turkey.

Until now, two Sequoioxylon species, Sequoioxylon egemenii (Özgüven-Ertan, 1971), and S. gypsaceum (now Taxodioxylon gypsaceum) (Özgüven-Ertan, 1981[1983]; Akkemik, 2019) were identified in Turkey. In S.egemenii, differently from S. gypsaceum, traumatic resin canals sometimes present and end walls of axial parenchyma predominantly smooth.

The identification showed that Taxodioxylon gypsaceum was the most common fossil species, and covered a huge area in Anatolia and its environs.

\section{Discussion and Conclusion}

The identified fossil species, Glyptostroboxylon rudolphii, is a typical element of swamp forests. Its modern representative, Glyptostrobus pensilis grows in the swamp and riparian conditions of Vietnam and South China (Eckenwalder 2009; Farjon 2010). This genus had different species and very wide areas in Miocene throughout Europe and Asia, but today restricted to very local swamp areas in China and Vietnam.

The identified fossil species, Taxodioxylon gypsaceum, is a member of riparian, well drained and warm to cool conditions. Its modern representative is mainly Sequoia sempervirens and grows in lowland riparian conditions of California shores generally below $300 \mathrm{~m}$ (Bannister and Neuner, 2001). This fossil species is the most common tree throughout Europe and Asia from Oligocene to Pliocene, and completely extinct from Europe and Asia in Pliocene.

This study and numerous palaeobotanical studies (e.g. Akgün et al. 2007; Akkiraz, 2011; Akkiraz et al., 2012; Velitzelos et al. 2014; Akkemik et al, 2016; Bouchal et al. 2016, 2017; Güner et al. 2017; Denk et al. 2017; Acarca Bayam et al. 2018) also suggested that swamp, riparian and warm-temperate conditions around the swamps and riparian areas were common in early Miocene to Pliocene in Turkey. Today in Turkey, riparian conditions are most common but swam conditions are very restricted.

The identified fossil species, Cupressinoxylon pliocenica from Gökçeada, where is an Aegean Island may indicate the presence of Mediterranean climate conditions. This fossil species was identified from the Pliocene time of north-central Anatolia for the first time, and this is the second wood of this fossil species. Denk et al. (2019) stated that "There was a globally averaged climate curves (cooler Burdigalian, warmer Langhian) and it was not necessarily seen in local floras. Thus, tropical plant groups might have gone through bottlenecks prior to mid-Miocene warming." For that reason, Cupressinoxylon and the other swamp species might have been growth in different regions or times of the early Miocene.

This result may also suggest that Cupressinoxylon pliocenica growth not only in Pliocene but also in the early Miocene. Today, only one species, Cupressus sempervirens, grows through the Mediterranean basin, and the fossil species may be suggested as the potential ancestor of this modern species, thanks to the close similarities. 


\section{Acknowledgements}

This paper was prepared by using the thin sections of the petrified woods housed at the Department of Forest Botany, Faculty of Forestry, Istanbul University-Cerrahpasa.

\section{References}

Acarca Bayam, N.N., Akkemik, Ü., Poole, I., Akarsu. F. (2018). Further Contributions to the early Miocene forest vegetation of the Galatean Volcanic Province, Turkey. Palaeobotanica Electronica, 21.3.40A 1-42. https://doi.org/10.26879/816palaeo-electronica.org/content/2018/2353-trees-of-gvp-in-miocene

Akgün, F., Kayseri, M. S., Akkiraz, M. S. (2007). Palaeoclimatic evolution and vegetational changes during the Late Oligocene-Miocene period in western and central Anatolia (Turkey). Palaeogeography, Palaeoclimatology, Palaeoecology, 253, 56-90.

Akkemik, Ü. (2019). New fossil wood descriptions from Pliocene of central Anatolia and presence of Taxodioxylon in Turkey from Oligocene to Pliocene. Turkish Journal of Earth Science, 28: 398-409, DOI:10.3906/yer-1805-24.

Akkemik, Ü., Acarca Bayam, N.N. (2019). The first Glyptostroboxylon and Taxodioxylon descriptions from the late Miocene of Turkey. Fossil Imprint, 75(2): 268-280.

Akkemik, Ü., Sakınç, M. (2013). Sequoioxylon petrified woods from the Mid to Late Oligocene of Thrace (Turkey). IAWA Journal, 34 (2):177-182. https://doi.org/10.1163/22941932-00000015

Akkemik, Ü., Yaman, B. (2012). Wood Anatomy of Eastern Mediterranean Species. Kessel Publishing House, Germany.

Akkemik, Ü., Acarca N.N., Hatipoğlu, M. (2017). The first Glyptostroboxylon from the Miocene of Turkey. IAWA Journal, 38(4):561-570. https://doi.org/10.1163/22941932-20170181

Akkemik, Ü., Akkılıç, H., Güngör, Y. (2019b). Fossil wood from the Neogene of the Kilyos coastal area in Istanbul, Turkey. Palaeontographica Abteilung B Palaeobotany - Palaeophytology. 299 (4-6): 133-185

Akkemik, Ü., Arslan M., Poole I., Tosun, S., Köse, N., Karlığlu Kılıç, N., Aydın, A. (2016). Silicified woods from two previously undescribed early Miocene forest sites near Seben, northwest Turkey. Review of Palaeobotany and Palynology 235:31-50,

https://doi.org/10.1016/j.revpalbo.2016.09.012

Akkemik, Ü., Kıran Yıldırım, D., Sakala, J., Akkılıç, H., Altınışık, A. (2019a). New petrified wood descriptions from west-central Anatolia: contribution to the composition of the Neogene forest of Turkey. Neues Jahrbuch für Geologie und Paläontologie, Abh., 292(1): 57-71. https://doi.org/10.1127/njgpa/2019/0808

Akkemik, Ü., Köse, N., Poole, I. (2005). Sequoioiodae (Cupressaceae) woods from the upper Oligocene of European Turkey (Thrace). Phytologia Balcanica, 11(2):119-131.

Akkemik, Ü., Mantzouka, D., Kıran Yıldırım, D. (2020). The first report of a new Lesbosoxylon species from the early -middle Miocene of eastern Anatolia. Geodiversitas. 42 (23): 427-441.

Akkemik, Ü., Türkoğlu, N., Poole, I., Çiçek, İ., Köse, N., Gürgen, G. (2009). Woods of a Miocene petrified forest near Ankara, Turkey. Turkish Journal of Agriculture and Forestry, 33:89-97. https://doi.org/10.3906/tar-0807-17

Akkiraz, M. S. (2011). Vegetation and climate in the Miocene deposits of southern side of Büyük Menderes Graben, Şahinali-2 core, SW Turkey. Bulletin of Geosciences, 86(4), 859-878.

Akkiraz, M. S., Akgün, F., Utescher, T., Wilde, V., Bruch, A. A., Mosbrugger, V., et al. (2012). Palaeoflora and climate of lignite-bearing lower-middle Miocene sediments in the Seyitömer and Tunçbilek sub-basins, Kütahya Province, Northwest Turkey. Turkish Journal of Earth Sciences, 21: 213-235.

Bamford, M., Zijlstra, G., Philippe, M. (2002). Proposal to conserve the name Cupressinoxylon against Retinodendron (fossil Gymnospermae, Coniferales), with a conserved type. Taxon, 51: 205-206 
Bannister, P., G. Neuner. (2001). Frost resistance and the distribution of conifers. P.3-22 in F.J. Bigras and S.J. Colombo (eds.), Conifer cold hardiness. Dordrecht: Kluwer Academic Publishers

Biondi, E., Brungiapaglia, E. (1991). Taxodioxylon gypsaceum in the fossil forest of Dunarobba (Umbria, Central Italy). Flora Mediterranea, 1:111-120.

Blokhina, N.I., Afonin, M.A., Kodrul, T.M. (2010). Fossil wood of Sequoioxylon burejense sp. nov. (Taxodiaceae) from the Upper Cretaceous of the Zeya-Bureya Basin (Russian Far East). Paleontological Journal, 44 (10): 12311239.

Bodnar, J., Ruiz, D.P., Artabe, A.E., Morel, E.M., Ganuza, D. (2015). Voltziales y Pinales (= Coniferales) de la Formación Cortaderita (Triásico Medio), Argentina, y su implicancia en la reconstrucción de las coníferas triásicas. Revista Brasileira de Paleontologia, 18: 141-160.

Bouchal, J. M., Zetter, R., Grímsson, F., Denk, T. (2016). The middle Miocene palynoflora and palaeoenvironments of Eskihisar (Yatağan Basin, southwestern Anatolia): a combined LM and SEM investigation. Botanical Journal of the Linnéan Society, 182(1), 14-79.

Bouchal, J. M., Mayda, S., Grímsson, F., Akgün, F., Zetter, R., Denk, T. (2017). Miocene palynofloras of the Tinaz lignite mine, Muğla, southwest Anatolia: taxonomy, palaeoecology and local vegetation change. Review of Palaeobotany and Palynology, 243, 1-36.

Denk, T., Güner, T. H., Kvaček, Z., Bouchal, M. J. (2017). The early Miocene flora of Güvem (Central Anatolia, Turkey): a window into early Neogene vegetation and environments in the Eastern Mediterranean - Acta Palaeobot., 57 (2): $237-338$.

Denk, T., Güner, H.T., Bouchal, M.J. (2019). Early Miocene climate and biomes of Turkey: Evidence from leaf fossils, dispersed pollen, and petrified wood. Palaeogeography, Palaeoclimatology, Palaeoecology 530: 236-248

Dolezych, M. (2011). Taxodiaceous woods in Lusatia (Central Europe), including curiosities in their nomenclature and taxonomy, with a focus on Taxodioxylon. Japanese Journal of Historical Botany, 19(1-2): 25-46.

Dolezych-Mikolai, M. (2005). Koniferenhölzer im 2. Lausitzer Flöz und ihre ökologische Position. PhD Thesis, LLP Contributions Series No. 19: 1-339, Utrecht.

Dolezych, M. \& Schneider, W. (2005). Taxonomie und Taphonomie von Braunkohlenhölzern und Cuticulae dispersae von Koniferen im 2. Lausitzer Flözhorizont (Miozän) des Senftenberger Reviers. LPP Contributions Series, $19,1-95$.

Dolezych, M. and Van der Burgh, J. (2004). Xylotomische Untersuchungen an inkohlten Hölzern aus dem Braunkohltegebau Berzdorf (Oberlausitz, Deutschland). Feddes Repertorium 115: 397-342.

Duperon-Laudoueneix M. (1979). Etude D’un bois Homoxyle du Tertiaire de Charente. (Ed: Boureau E.) Comptes Rendus Du 104e Congres National des Societes Savantes. Bordeaux, 1979. Section Des Science. Paleobotanique pp: 249-262.

Eckenwalder, J.E. (2009). Conifers of the World: The complete reference. Timber Press, London.

Farjon, A. (2010). A Handbook of the World's Conifers, V.1-2. Brill Academic Publishers, Leiden-Boston.

Greguss, P. (1967). Fossil Gymnosperm Woods in Hungary, from Permian to Pliocene. Academia Kiado, Budapest.

Güner, H. T., Bouchal, J. M., Köse, N., Göktaş, F., Mayda, S., Denk, T. (2017): Landscape heterogeneity in the Yatağan Basin (southwestern Turkey) during the middle Miocene inferred from plant macrofossils. Palaeontolographica Abt. B, 296 (1-6): 113-171.

Güngör, Y., Akkemik, Ü., Kasapçi, C., Başaran, E. (2019). Geology and woods of a new fossil forest from the early Miocene of Gökçeada (Turkey) - Forestist. 69 (1): 22-34. 
Herbst, R., Brea, M., Crisafulli, A., Gnaedinger, S., Lutz, A.I., Martinez, L. (2007). La paleoxilologia en la Argentina. Historia y desarrollo. Buenos Aires, Asociación Paleontológica Argentina, 11(Special publication), 50 aniversario de Ameghiniana 57-71.

Iamandei, S., Iamandei, E., Sabou-Dumitrescu, M. (2013). New petrified woods from Căprioara Valley, Feleacu Hill, Cluj, Romania. Romanian Journal of Earth Sciences, 8 (1): 1-27.

IAWA Committee. (2004). IAWA list of microscopic features for softwood identification. IAWA Journal, 25:1-70.

Kayacık, H., Aytuğ, B., Yaltırık, F., Şanlı, I., Efe, A., Akkemik, Ü., Inan, M. (1995). Sequoiadendron giganteum (Lindl) Buchh. trees living near Istanbul in Late Tertiary. Rev. of Fac. of Forestry, University of Istanbul, 45: 15-22.

Kłusek, M. (2014). Miocene coniferous woods of the Polish Carpathian Foredeep. Acta Palaeontologica Polonica, 59 (3): 697-708.

Koutecký, V., Sakala, J. (2015). New fossil woods from the Paleogene of Doupovske Hory and Ceske Stredohori Mts. (Bohemian Massif, Czech Republic). Acta Musei Nationalis Pragae. Series B-Historia Naturalis, 71: 377-398.

Kräusel, R. (1949). Die fossilen Koniferen-Hölzer (Unter Ausschluß von Araucarioxylon Kraus). II: Kritische Untersuchungen zur Diagnostik lebender und fossiler Koniferen-Hölzer. Palaeontographica B, 89:83-203.

Kutluk, H., Kır, O., Akkemik, Ü. (2012). First report of Araucariaceae wood (Agathoxylon sp.) from the late Cretaceous of Turkey. IAWA Journal, 33 (3): 316-326.

Martinez, L.C. (2010). Prosopisinoxylon anciborae nov. gen. et sp. (Leguminosae, Mimosoideae) from the Late Miocene Chiquimil Formation (Santa Maria Group), Catamarca, Argentina. Review of Palaeobotany and Palynology, 158(3): 262-271.

Nishida, M. (1984). The anatomy and affinities of the petrified plants from the Crete-Tertiary of Chile, Ill Petrified woods from Mocha Island, Central Chile. In: Nishida M (ed.). Contributions to the Botany in the Andes, I. Academia Scientific Book, Tokyo 98-110.

Nishida, M., Nishida, H., Nasa, T. (1988). Anatomy and affinities of the petrified plants from the Tertiary of Chile. V. Bot. Mag., Tokyo, 101: 293-309.

Özgüven-Ertan, K. (1971). Sur un bois fossile de Taxodiaceae dans la flore Neogene d'Istanbul (Turquie d'Europe): Sequoioxylon egemeni n.sp. Rev Fac Sci l'Université d'Istanbul, 36 (B): 89-114.

Özgüven-Ertan, K. (1977). La stucture D’une Cupressaceae fossile appartenant au Miocene Trouvee dans la region D'egee en Turquie: Cupressinoxylon akdiki n.sp. Rev. Fac. Sci. l'Université d'Istanbul, 42 (B1-2): 1-15.

Özgüven-Ertan, K. 1981 [1983]. Sequoioxylon gypsaceum (Göeppert) Greguss bois fossile du Tertiaire D’Ankara Beypazar1 (Turquie). Rev Fac Sci l'Université d'Istanbul, 46 (B): 21-28.

Philippe, M., Bamford, M. (2008). A key to morphogenera used for Mesozoic conifer-like woods. Review of Palaeobotany and Palynology, 148: 184-207.

Polat, S., Güney, Y., Ege, İ., Akkemik, Ü. (2019). The first findings on fossil trees area located in Banaz (Uşak), Turkish Journal of Geographical Sciences, 17(2): 384-402, doi: 10.33688/ aucbd.532176 [in Turkish].

Pujana, R.R., Panti, C., Cuitino, J.I., Massini, G., Mirabelli, S.L. (2015). A new megaflora (fossil woods and leaves) from the Miocene of southwestern Patagonia. Ameghiniana 52(3): 350-366.

Pujana, R.R., Santillana, S.N., Marenssi, S.A. (2014). Conifer fossil woods from the La Meseta Formation (eocene of Western Antarctica): evidence of Podocarpaceae-dominated forests. Review of Palaeobotany and Palynology, 200: 199-204.

Selmeier, A. (2001). Silicified Miocene woods from the North Bohemian Basin (Czech Republic) and from Kuzuluk, district Adapazari (Turkey). Mitteilungen der Bayerischen Staatssammlung für Paläontologie und Histor. Geologie, 41:111-144 
Süss, H., Velitzelos, E. (1997). Fossile Hölzer der Familie Taxodiaceae aus tertiären Schichten des Versteinerten Waldes von Lesbos, Griechenland. Feddes Repertorium, 1-2:1-30.

Teodoridis, V., Sakala, J. (2008). Early Miocene conifer macrofossils from the Most Basin (Czech Republic). - Neues Jahrbuch für Geologie und Paläontologie- Abhandlungen, 250: 287-312.

Tian, N., Zhu, Z., Wang, Y., Philippe, M., Chou, C., Xie, A. (2018). Sequoioxylon zhangii sp. nov. (Sequoioideae, Cupressaceae s.1.), a new coniferous wood from the Upper Cretaceous in Heilongjiang Province, Northeast China. Review of Palaeobotany and Palynology, 257: 85-94.

Vaudois, N., Privé, C. (1971). Révision des bois fossiles de Cupessaceae. Palaeontographica B 134: 61-86.

Velitzelos, D., Bouchal, J.M., Denk, T. (2014). Review of the Cenozoic floras and vegetation of Greece. Review of Palaeobotany and Palynology 204: 56-117

Submitted: 24.08.2020 Accepted: 24.09.2020 